\title{
T lymphocyte insensitivity to corticosteroids in chronic obstructive pulmonary disease
}

\author{
Manminder Kaur ${ }^{1 \dagger}$, Lucy JC Smyth ${ }^{1,3+}$, Paul Cadden', Seamus Grundy ${ }^{1}$, David Ray ${ }^{2}$, Jonathan Plumb ${ }^{1}$ and \\ Dave Singh ${ }^{1^{*}}$
}

\begin{abstract}
Background: There are increased numbers of activated lymphocytes in the lungs of chronic obstructive pulmonary disease (COPD) patients. The clinical benefits of corticosteroids in COPD patients are limited. Our hypothesis is that lymphocytes play a role in this corticosteroid insensitivity.

Objectives: To investigate the effects of the corticosteroid dexamethasone on lung lymphocyte cytokine production from patients with COPD compared to controls.

Methods: Cultured airway lymphocytes obtained by bronchoscopy from healthy non-smokers (HNS), smokers (S) and COPD patients were stimulated with phytohaemagglutinin (PHA) \& phorbol myristate acetate (PMA), +/dexamethasone. Supernatants were assayed for interleukin (IL)-2 and interferon (IFN) $\gamma$. Immunofluoresence was used to analyse changes in CD8 glucocorticoid receptor (GRo and GRß) expression.
\end{abstract}

Results: The inhibition of PHA/PMA stimulated IFN $\gamma$ production by dexamethasone was reduced in COPD patients compared to HNS $(p<0.05$ at concentrations from 0.1-1 $\mu \mathrm{M})$. There was also a significant reduction $(p<0.05)$ in the mean inhibitory effect at $1 \mu \mathrm{M}$ in COPD patients (54.1\%) compared to smokers (72.1\%), and in smokers compared to HNS (85.5\%). There was a numerically reduced effect of dexamethasone on IL-2 production that did not reach statistical significance. There was no difference in GR $\alpha$ and GR $\beta$ expression in follicular CD8 cells between COPD patients (50.9\% and 30.4\% respectively) and smokers (52.9\% and $29.7 \%$ respectively).

Conclusions: IFNy production from COPD airway lymphocytes is corticosteroid insensitive. This phenomenon may be important in the poor clinical response often observed with corticosteroids.

Keywords: COPD, Lymphocytes, Corticosteriods

\section{Background}

Chronic obstructive pulmonary disease (COPD) is a progressive inflammatory airway disease. There are increased numbers of lymphocytes, particularly CD8 cells, in the lungs of COPD patients leading to the suggestion that COPD has an autoimmune component [1-3]. CD8 cells are increased in the airway lumen, subepithelium and parenchyma and their numbers increase proportionate to disease severity [1]. T lymphocytes from the airways of COPD patients produce pro-

\footnotetext{
* Correspondence: dsingh@meu.org.uk

+ Contributed equally

'University of Manchester, Manchester Academic Health Science Centre, NIHR Translational Research Facility, University Hospital of South Manchester

Foundation Trust, Southmoor Road, Manchester, UK M23 9LT

Full list of author information is available at the end of the article
}

inflammatory cytokines, with evidence of both Th1 and Th2 cytokine production [4-8]. Furthermore, there is an increase in organised lymphoid structures called follicles within the lung parenchyma and associated with the bronchial tree [9]. These follicles may function as antigen presenting sites, further supporting the hypothesis that COPD has an autoimmune component [10].

Corticosteroids are the most widely used anti-inflammatory drug in COPD patients. Corticosteroids bind to the cytoplasmic glucocorticoid receptor (GR), forming a complex that can suppress inflammatory gene transcription [11]. However, the clinical benefits of corticosteroid therapy in COPD are limited [12-14]. Using peripheral blood derived lymphocytes, it has been demonstrated that corticosteroids have reduced effects on phytohaemagglutinin (PHA)-induced lymphoproliferative

\section{Biomed Central}


responses in patients with rheumatoid arthritis, ulcerative colitis and corticosteroid resistant asthma [15-18]. Our hypothesis was that COPD airway T lymphocytes also have reduced sensitivity to the effects of corticosteroids.

We report an investigation of the corticosteroid sensitivity of airway $\mathrm{T}$ lymphocytes from COPD patients compared to controls. The effect of dexamethasone on bronchoalveolar lavage (BAL) T lymphocyte cytokine production was investigated. In order to establish whether altered GR expression plays a role in corticosteroid sensitivity in lymphocytes; GR expression was quantified in CD8 cells of COPD patients and smoking controls.

\section{Methods}

\section{Study subjects}

14 COPD patients, 10 smokers with normal lung function and 10 healthy non smokers (HNS) were recruited (demographics shown in Table 1). Some of these patients were recruited specifically to undergo a bronchoscopy for research purposes (6 COPD patients, 3 smokers and $7 \mathrm{HNS}$ ). The remaining patients were undergoing clinical investigational bronchoscopies for the following reasons; haemoptysis (3 COPD patients, 1 smoker, 3 HNS), unexplained shortness of breath or weight loss (2 COPD patients, 2 smokers), and investigation of abnormal chest X-ray findings suggestive of lung

Table 1 Subject Demographics data are expressed as means (SD)

\begin{tabular}{|c|c|c|c|c|c|}
\hline & $\begin{array}{l}\text { COPD } \\
\mathrm{N}=14\end{array}$ & $\begin{array}{l}\text { Smokers } \\
\mathrm{N}=10\end{array}$ & $\begin{array}{l}\mathrm{HNS} \\
\mathrm{N}=10\end{array}$ & $\begin{array}{l}\text { COPD } \\
N=10 \\
I F\end{array}$ & $\begin{array}{l}\text { Smokers } \\
\mathrm{N}=11 \\
\mathrm{IF}\end{array}$ \\
\hline$\overline{\operatorname{Sex}(F / M)}$ & $4 / 10$ & $3 / 7$ & $5 / 5$ & $4 / 6$ & $5 / 6$ \\
\hline Age (years) & $\begin{array}{l}66.9 \\
(7.3)\end{array}$ & $\begin{array}{l}62.4 \\
(20.6)\end{array}$ & $\begin{array}{l}39.5 \\
(22.4)\end{array}$ & $\begin{array}{l}65.2 \\
(6.8)\end{array}$ & $66.1(8.6)$ \\
\hline Gold Stage (1/2/3) & $0 / 13 / 1$ & N/A & N/A & $3 / 6 / 1$ & N/A \\
\hline $\mathrm{FEV}_{1}(\mathrm{~L})$ & $1.8(0.6)$ & $2.0(0.9)$ & $3.4(1.2)$ & $\begin{array}{l}2.01 \\
(0.5) \\
\end{array}$ & $2.06(0.5)$ \\
\hline $\mathrm{FEV}_{1} \%$ predicted & $62(12)$ & $98(19)$ & $100(15)$ & $\begin{array}{l}70.4 \\
(11.5) \\
\end{array}$ & $\begin{array}{l}86.4 \\
(19.3) \\
\end{array}$ \\
\hline $\mathrm{FEV}_{1} / \mathrm{FVC}$ ratio & $\begin{array}{l}56 \\
(13.8)\end{array}$ & $77(5.7)$ & $83(6.0)$ & $\begin{array}{l}60.8 \\
(11.1)\end{array}$ & $73.8(7.7)$ \\
\hline Pack year history & $\begin{array}{l}40.7 \\
(26.4)\end{array}$ & $\begin{array}{l}37.2 \\
(28.5)\end{array}$ & 0 & $\begin{array}{l}49.2 \\
(39.7)\end{array}$ & $\begin{array}{l}62.3 \\
(29.5)\end{array}$ \\
\hline Current/Ex smoker & $5 / 9$ & $5 / 5$ & N/A & $9 / 1$ & $11 / 0$ \\
\hline ICS Users & 6 & 0 & 0 & 2 & 0 \\
\hline$\overline{B A L}$ Yield (mls) & $\begin{array}{l}91.0 \\
(76.3)\end{array}$ & $\begin{array}{l}115 \\
(109)\end{array}$ & $\begin{array}{l}190 \\
(131)\end{array}$ & N/A & N/A \\
\hline $\begin{array}{l}\text { Total Cell Yield/ml } \\
\left(\times 10^{6}\right)\end{array}$ & 0.23 & 0.28 & 0.13 & N/A & N/A \\
\hline $\begin{array}{l}\text { Total Lymphocytes } \\
\text { (\%) }\end{array}$ & 6.9 & 6.6 & 7.6 & N/A & N/A \\
\hline
\end{tabular}

cancer (3 COPD patients and 4 smokers). Subjects with any other pulmonary conditions including history of asthma were excluded. For immunofluorescent analysis, 10 COPD patients and 11 smokers with normal lung function, undergoing surgical resection for suspected or confirmed lung cancer were recruited. Tissue blocks were preselected for this study based on the presence of at least one inflammatory follicle. COPD patients were diagnosed based on a history of smoking ( $>10$ pack years), typical symptoms and airflow obstruction $\left(\mathrm{FEV}_{1}\right.$ $<80 \%$ predicted, and $\mathrm{FEV}_{1} / \mathrm{FVC}$ ratio < 0.7) [19]. All subjects gave written informed consent. The study was approved by the local research ethics committee.

\section{Cell collection}

BAL was collected from the upper lobes, or a lobe not affected by radiographic or endobronchial abnormalities: The bronchoscope was wedged in the bronchus and a maximum of $4 \times 60 \mathrm{ml}$ aliquots of pre-warmed sterile $0.9 \% \mathrm{NaCl}$ solution were instilled into each lobe. The aspirated fluid was stored on ice before filtration (100 $\mu \mathrm{m}$ filter, Becton Dickenson). The filtrate was centrifuged $\left(400 \mathrm{~g} / 10 \mathrm{~min}\right.$ at $\left.4^{\circ} \mathrm{C}\right)$ and the cell pellet resuspended in RPMI 1640 medium supplemented with 2 $\mathrm{mM}$ L-glutamine, $100 \mathrm{U} / \mathrm{ml}$ penicillin, and $100 \mu \mathrm{g} / \mathrm{ml}$ streptomycin. Viable cell counts were determined by trypan blue exclusion (Neubauer hemocytometer) and adjusted to $1 \times 10^{6}$ cells $/ \mathrm{ml}$. Macrophages were depleted by adherence by 90 minute incubation in a 24 well plate at $37^{\circ} \mathrm{C}, 5 \% \mathrm{CO}_{2}$. The non adherent cell count was adjusted to $2 \times 10^{6}$ cells $/ \mathrm{ml}$ in supplemented RPMI 1640 medium with additional 10\% (vol/vol) fetal calf serum. This cell suspension was then used for cell culture.

\section{Cell Culture}

$1 \times 10^{5}$ cells (non adherent BAL), were seeded in a 96 well plate $+/$ - dexamethasone $(1,0.1 \& 0.01 \mu \mathrm{M})$ for 2 hours at $37^{\circ} \mathrm{C}, 5 \% \mathrm{CO}_{2}$ in $200 \mu \mathrm{l}$ RPMI-1640 media supplemented with $2 \mathrm{mM}$ L-glutamine, $100 \mathrm{U} / \mathrm{ml}$ penicillin, and $100 \mu \mathrm{g} / \mathrm{ml}$ streptomycin and 10\% FCS (v/v). Subsequently lymphocytes were activated by addition of PHA and phorbol myristate acetate (PMA), $10 \mu \mathrm{g} / \mathrm{ml}$ each. Cells were further incubated for 24 hours. This time point was chosen based on initial time course experiments over 2 days in 3 smoking subjects (data not shown). Supernatants $(180 \mu \mathrm{l})$ were harvested by plate centrifugation $10 \mathrm{mins}, 400 \mathrm{~g}, 4^{\circ} \mathrm{C}$ and transferred to a fresh 96 well plate for storage at $-20^{\circ} \mathrm{C}$ prior to ELISA analysis.

\section{ELISA assay}

Release of interleukin (IL)-2 and interferon (IFN) $\gamma$ was assayed on cell culture supernatants (either undiluted or 
up to 1:5 dilution with RPMI containing 10\% FCS as required) using R\&D systems ELISA duosets according to manufacturer's instructions.

\section{Dual-label Immunofluorescence}

Tissue blocks were obtained from an area of the lung as far distal to the tumour as possible, and processed as described previously [20]. Lung tissues were cut into 4$\mu \mathrm{m}$ sections and lifted onto a polysine coated glass slide. For heat induced epitope retrieval in $0.01 \mathrm{M}$ trisodium buffer $\mathrm{pH} 6$ the lung sections were microwaved for 20 min at $800 \mathrm{~W}$. A cocktail of CD8 with either GR $\alpha$ or GR $\beta$ primary antibodies diluted in $1.5 \%$ normal serum (Vector Labs, Peterborough, UK) with $0.5 \%$ triton $\times 100$ was applied overnight at $4^{\circ} \mathrm{C}$. Two CD8 primary antibodies were used to avoid applying a cocktail with two antibodies requiring the same species secondary antibody.

According to primary antibody species requirements, CD8 and GR were detected using either Alexa 568 conjugated goat anti-rabbit immunoglobulin IgG (1:200, Invitrogen, Paisley, UK) and Alexa 488 conjugated goat anti-mouse immunoglobulin IgG secondary antibodies (1:200, Invitrogen) respectively. Sections were counterstained with 4,6-diamidino-2-phenylindole (DAPI, Invitrogen). Omission of primary antibody from staining protocol was used as a negative control.

\section{Image Analysis}

The number of $\mathrm{CD} 8^{+} \mathrm{GR} \alpha^{+}$and $\mathrm{CD} 8^{+} \mathrm{GR} \beta^{+}$cells within inflammatory follicles were calculated and presented as a percentage of the CD8 population. Digital micrographs were obtained using a Nikon Eclipse 80i microscope (Nikon UK Ltd, Surrey, UK) equipped with a QImaging digital camera (Media Cybernetics, Marlow UK) and ImagePro Plus 5.1 software (Media Cybernetics).

\section{Data analysis \& Statistics}

IL-2 and IFN $\gamma$ data were not normally distributed, and so comparisons between groups were performed using a non-parametric ANOVA. If the ANOVA was significant $(\mathrm{p}<0.05)$, then subsequent Mann Whitney $\mathrm{U}$ tests were performed for pairwise comparisons. Data for the percentage inhibition by dexamethasone were parametric. Paired t-tests were used to compare the effects of dexamethasone to PHA/PMA alone. Between group comparisons were performed by ANOVA. If the ANOVA was significant $(\mathrm{p}<0.05)$, then subsequent two way comparisons were performed using an unpaired t-test. Immunofluorescence data were normally distributed; comparisons between groups were performed using unpaired t-tests. All analysis was carried out using GraphPad Prism version 5 (GraphPad Software, Inc., San Diego, CA, USA).

\section{Results}

The cell yields/ml of recovered BAL fluid were numerically greater in COPD patients and smokers compared to HNS although this did not reach statistical significance $(p=0.2)$ (see Table 1). There was no difference between groups in the proportion of lymphocytes present.

\section{Cytokine Production}

Figure 1 \& Table 2 show that unstimulated IFN $\gamma$ levels and IL-2 levels were not significantly different between subject groups (ANOVA $p=0.6$ and 0.9 respectively). PHA and PMA stimulation for 24 hours significantly increased the secretion of both IFN $\gamma$ and IL-2 in all 3 subject groups ( $p<0.001$ for all comparisons of unstimulated vs stimulated levels). There was no statistical difference in stimulated IL-2 levels between groups (ANOVA $p=0.2$ ). Stimulated IFN $\gamma$ levels were different between groups (ANOVA $p=0.04$ ), as there were lower levels in HNS compared to smokers (Mann Whitney Unpaired t test $p=0.04$ ). There was also significantly lower IFN $\gamma$ levels in COPD compared to HNS and smokers (Mann Whitney U test $p=0.04$ ).

\section{Dexamethasone effects}

Dexamethasone at all concentrations $(0.01-1 \mu \mathrm{M})$ inhibited stimulated IFN $\gamma$ production in all 3 subject groups; the absolute cytokine levels with and without dexamethasone are shown in Figure 1. As the PHA/ PMA stimulated IFN $\gamma$ levels were different between subject groups, the effect of dexamethasone was normalised to the PHA/PMA levels without dexamethasone and shown in Figure 2 as percentage inhibition. There was a significant difference between groups for the effect of dexamethasone on IFN $\gamma$ production at $1 \mu \mathrm{M}$ and 0.1 $\mu \mathrm{M}$ (ANOVA $p<0.05$ for between group comparisons), with the difference between groups not quite reaching significance at $0.01 \mu \mathrm{M}$. The highest concentration of dexamethasone $(1 \mu \mathrm{M})$ only achieved a mean inhibition of $54.1 \%$ of IFN $\gamma$ production in COPD subjects. Subsequent two way comparisons showed that the inhibition of IFN $\gamma$ was significantly less in COPD patients compared to HNS at $1 \mu \mathrm{M}$ (Unpaired t test $p=0.001$ ) and $0.1 \mu \mathrm{M}$ (Unpaired t test $p=0.005$ ). At $1 \mu \mathrm{M}$ there were also significant differences between COPD patients and smokers (Unpaired t test $p=0.05$ ), and between HNS and smokers (Unpaired test $\mathrm{t} p=0.05$ ).

Dexamethasone at all concentrations $(0.01-1 \mu \mathrm{M})$ inhibited stimulated IL-2 production in all 3 subject groups. There was less inhibition of IL-2 production in COPD patients at all 3 concentrations, but these numerical differences between groups did not reach statistical significance $(p>0.05)$.

Within the COPD group, dexamethasone had similar effects on current and ex smokers for both IL-2 and 

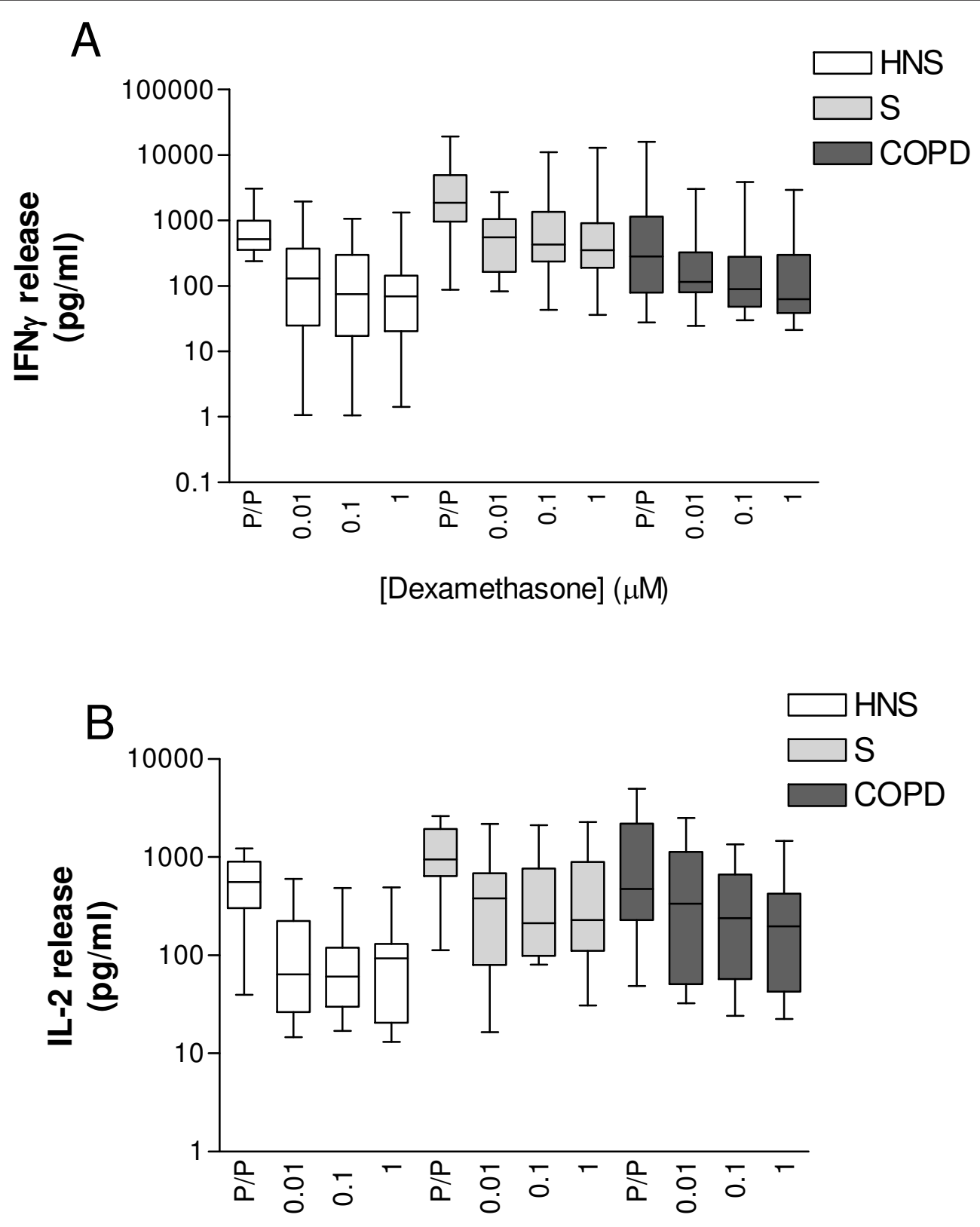

[Dexamethasone] $(\mu \mathrm{M})$

Figure 1 PHA/PMA induced IFN $\gamma(A)$ and IL-2 (B) release $(\mathrm{pg} / \mathrm{ml})$ from cultured BAL lymphocytes from healthy non-smokers $(\mathrm{HNS})(\mathrm{n}=$ 10 light bars), healthy smokers (S) ( $n=10$ mid grey bars) and COPD patients ( $n=14$ dark grey bars). Cells were pre- treated for 2 hours with dexamethasone $(0.01-1 \mu \mathrm{M})$ prior to 24 hours T cell stimulation with PHA/PMA (P/P) $10 \mu \mathrm{g} / \mathrm{ml}$ each. Data is presented as median (range).

IFN $\gamma$ production ( $p>0.05$ for comparisons at each concentration) (data not shown).

\section{GR expression in follicles}

There were no significant differences between the percentage of follicular CD8 cells that expressed either GR $\alpha$ or GR $\beta$ between COPD patients (means $50.9 \%$ and $30.4 \%$ respectively) and controls (mean $52.9 \%$ and $29.7 \%$ respectively), $\mathrm{p}=0.8$ and 0.9 respectively; see Figure 3 for individual data and representative images.

\section{Discussion}

We show that the sensitivity of airway lymphocytes to corticosteroids is reduced in COPD patients. Our results implicate these cells as important players in the clinical phenomenon of corticosteroid resistance in COPD. 
Table 2 Basal and stimulated cytokine release from healthy non smokers (HNS), smokers \& COPD.

\begin{tabular}{cccc}
\hline \multirow{2}{*}{$\begin{array}{c}\text { BASAL } \\
\text { (A) }\end{array}$} & HNS & $\begin{array}{c}\text { IFN } \boldsymbol{\gamma} \text { release } \\
\mathbf{p g} / \mathbf{m l})\end{array}$ & $\begin{array}{c}\text { IL-2 release } \\
\mathbf{( p g / m l})\end{array}$ \\
\cline { 2 - 4 } & & $9.8(3.9-651)$ & $14.5(6.2-39.8)$ \\
& Smokers & $16.3(0-75.1)$ & $20.6(0-453.6)$ \\
\cline { 2 - 4 } & COPD & $17.3(0-83)$ & $29.6(0-102.8)$ \\
\cline { 2 - 4 } & $\mathbf{P}$ value & $\mathbf{0 . 6}$ & $\mathbf{0 . 9}$ \\
\hline $\begin{array}{c}\text { PHA/PMA } \\
\text { (B) }\end{array}$ & HNS & $519(239.4-3062)$ & $557.6(39.6-1228)$ \\
& & & \\
\cline { 2 - 4 } & Smokers & $1881(87.1-19217)$ & $954.9(112.7-2612)$ \\
\cline { 2 - 4 } & COPD & $284.6(27.6-15992)$ & $474.2(28.9-5011)$ \\
\cline { 2 - 4 } & $\mathbf{P}$ value & $\mathbf{0 . 0 4}$ & $\mathbf{0 . 2}$ \\
\hline
\end{tabular}

Data are expressed as median (range).

ANOVAs for basal (A) and stimulated (B) between group comparisons are shown beneath each column
IFN $\gamma$ plays a key role in Th1 type inflammation and cell mediated cytotoxicity (reviewed [21]). We show that corticosteroids have a reduced inhibitory effect on IFN $\gamma$ production in COPD patients. The clearest difference in corticosteroid sensitivity observed was between COPD patients and HNS, although there was also evidence of differences between COPD patients and smokers, and between smokers and HNS at the highest dexamethasone concentration $(1 \mu \mathrm{M})$. These data suggest that smoking itself reduces $\mathrm{T}$ lymphocyte corticosteroid sensitivity, and that the development of COPD further reduces corticosteroid sensitivity.

IL-2 is an integral cytokine for T lymphocyte proliferation [22]. There were numerical trends suggesting a reduction in the inhibitory effect of dexamethasone on IL-2 production in COPD patients compared to controls, but these did not reach statistical significance.
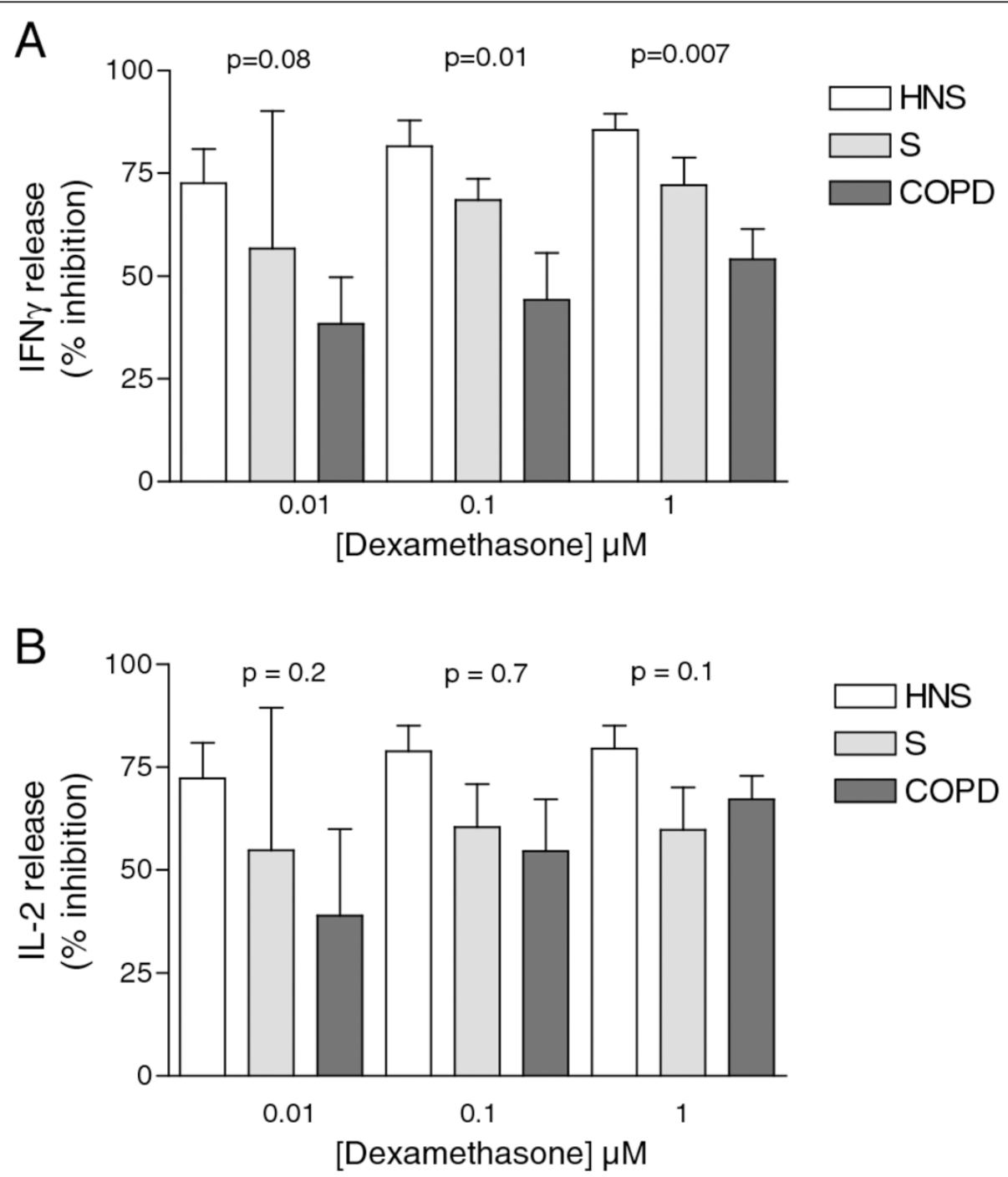

Figure 2 Reduction of PHA/PMA induced IFN $\gamma(\mathrm{A})$ and IL-2 (B) release was converted from $\mathrm{pg} / \mathrm{ml}$ into percent inhibition. Healthy nonsmokers (HNS) ( $n=10$ light bars), healthy smokers (S) ( $n=10$ mid grey bars) and COPD patients ( $n=14$ dark grey bars). Data are expressed as mean $( \pm \mathrm{SD})$. P-values from ANOVAs for between group comparisons are shown. 

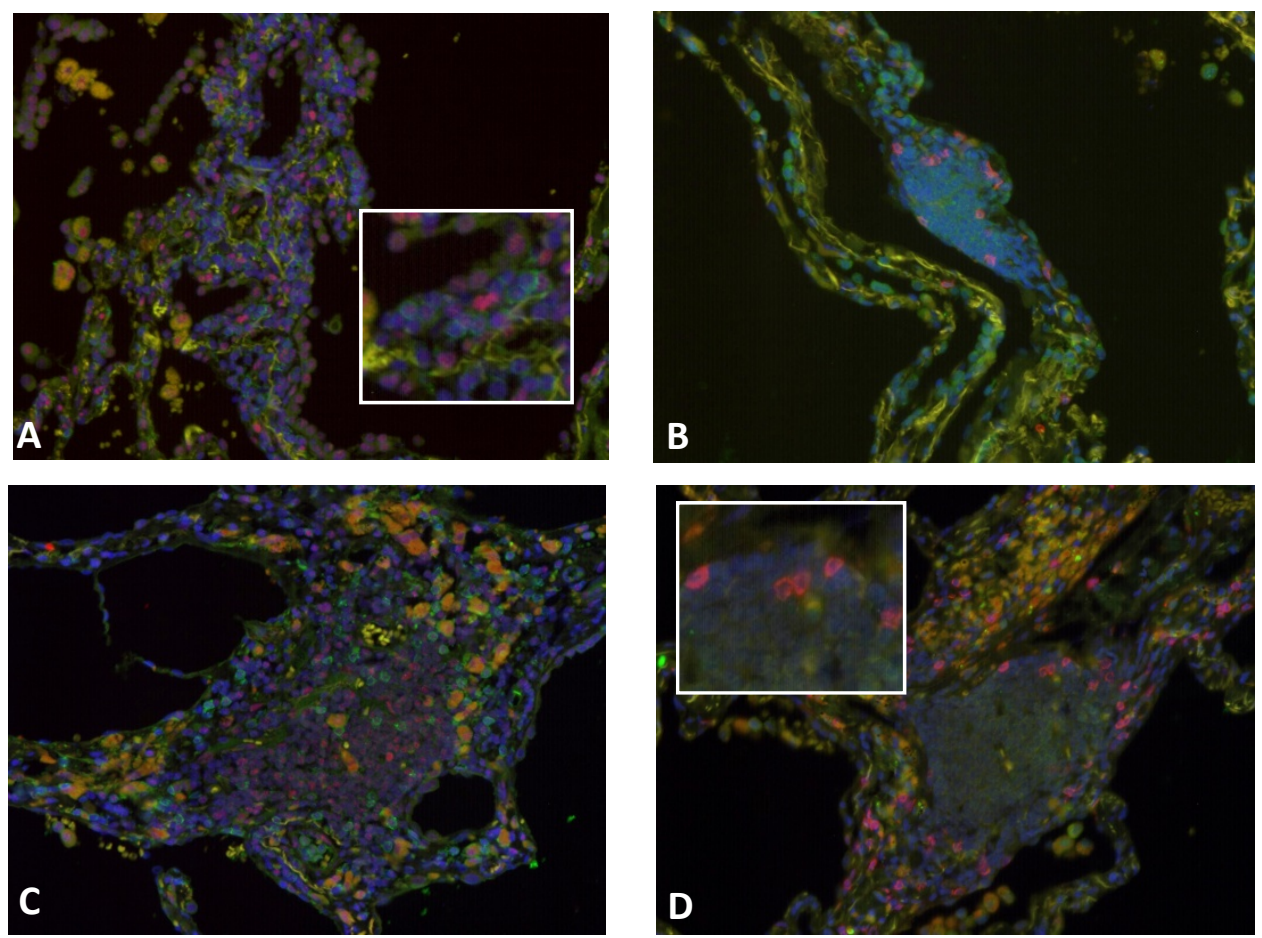

$\mathbf{E}$

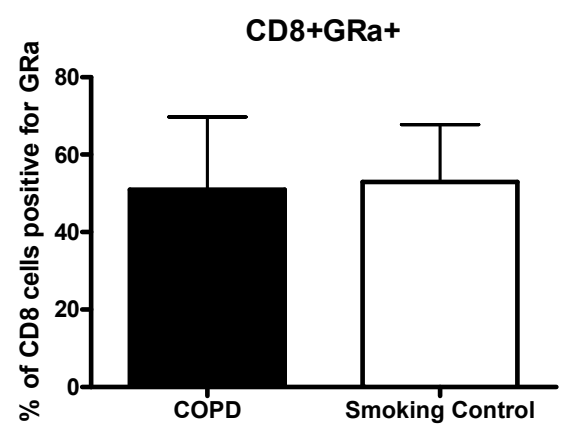

$\mathbf{F}$

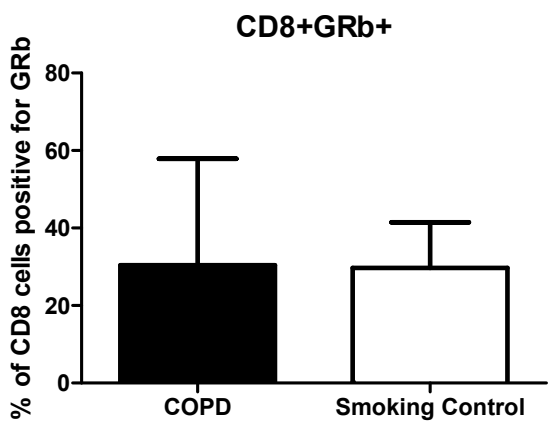

Figure 3 Representative images for the dual immunofluorescence detection of $\mathrm{CD} 8^{+} \mathrm{GR} \alpha^{+}$and $\mathrm{CD} 8^{+} \mathrm{GR} \beta^{+} \mathrm{T}$ - cells within human lung tissue from (A\&B) a COPD subject and (C\&D) a smoking control subject. (A\&C) CD8 $8^{+}$cells were identified using an Alexa-488 conjugated goat anti-rabbit secondary antibody (Green stain) and GR $\alpha^{+}$cells were detected using an Alexa-568 conjugated goat anti-mouse secondary antibody (Red stain). (B\&D) CD8 ${ }^{+}$cells were identified using an Alexa-568 conjugated goat anti-mouse secondary antibody (Red stain) and GR $\beta^{+}$ cells were detected using an Alexa-488 conjugated goat anti-rabbit secondary antibody (Green stain). Cell nuclei were counterstained with 4', 6diamidino-2-phenylindole (DAPI, blue stain). Magnification $\times$ 200. (E\&F) Analysis of the number of CD8+ cells that were also positive for GR $\alpha$ and GR $\beta$, within COPD $(n=10)$ and smoking control $(n=11)$ follicles. Data presented as mean + SD.

This indicates that the effects of corticosteroids vary between $\mathrm{T}$ lymphocyte cytokines, with IFN $\gamma$ showing more corticosteroid resistance in COPD patients compared to IL-2. The molecular mechanisms for such a difference have not been explored. The ability of corticosteroids to regulate the activity of transcription factors such as nuclear factor of activated T-lymphocytes (NFAT), activator protein 1 (AP-1), nuclear factor kappa-light-chain-enhancer of activated B cells (NF- $\kappa \mathrm{B})$ and activating transcription factor (ATF) may vary between the promoter regions of the IL- 2 and IFN $\gamma$ genes, and may be further altered by changes such as chromatin modulation that may occur in response to oxidative stress and inflammation in COPD [23].

Corticosteroid insensitivity has been observed in peripheral blood lymphocytes of corticosteroid resistant patients with asthma, ulcerative colitis and rheumatoid arthritis, as well as renal transplant recipients [14-16,24]. 
IL-2 may play a key role in this phenomenon, as it can induce corticosteroid insensitivity in murine $\mathrm{T}$ lymphocytes [25] as well as in PBMCs from healthy volunteers by reducing GR binding affinity [26]. IL-2 mRNA levels are increased in the BAL of steroid resistant patients with asthma [27]. We speculate that IL-2 may play a role in the corticosteroid insensitivity observed in the current study.

IFN $\gamma$ predisposes the airway microenvironment to a proinflammatory Th1 environment and plays a key role in host defence against viruses [28]. Pulmonary IFN $\gamma$ levels are increased in COPD patients [29-31], and it has also been reported that COPD severity is related to the degree of IFN $\gamma$ production by CD8 cells [32]. Viral infections can increase IFN $\gamma$ levels in COPD patients $[33,34]$.

Our data suggests that that lymphocyte IFN $\gamma$ production is corticosteroid resistant in COPD patients. This raises the possibility that virally induced IFN $\gamma$ production in COPD patients is poorly suppressed by corticosteroids; the poor response of viral exacerbations of COPD to corticosteroids is an observation frequently noted by clinicians treating exacerbations.

The number of $\mathrm{T}$ lymphocytes in the lungs increases with the severity of COPD $[1,35,36]$. These $\mathrm{T}$ lymphocytes display an increased Th1 response $[4,7]$. Results in this study suggest that IFN $\gamma$ could play a central role in persistent Th1 inflammation in COPD, as it responds poorly to corticosteroids. Novel therapies that specifically target IFN $\gamma$ activity may reduce Th1 inflammation in COPD, such as targeting of the janus kinase $(J A K)$ signal transducer and activator of transcription (STAT) pathway [37].

Our data suggests that IFN $\gamma$ release from COPD lymphocytes is reduced compared to controls. This finding differs from studies that show increased IFN $\gamma$ production from COPD lymphocytes [4,7], and increased levels of IFN $\gamma$ in the airways of COPD patients compared to controls [29-31]. We observed a similar trend for lower IL-2 production in COPD, although this did not reach statistical significance. Reduced cytokine production by alveolar macrophages has been reported from smokers and patients with COPD [38-40] which is thought to be due to a "blunting" effect of cigarette smoke on cell signalling mechanisms such as p38 mitogen activated protein kinase and $\mathrm{NF} \kappa \mathrm{B}$ [40]. It is possible that a similar effect is also present in COPD lymphocytes. However, as this phenomenon has not been observed in previous studies of COPD lymphocytes [35,36], it is also possible that our findings for both IFN $\gamma$ and IL-2 are due to random individual variation in a limited sample size rather than a true biological effect.

Corticosteroids bind to GR forming a complex that translocates to the nucleus to interfere with the binding of transcription factors such as NF- $\kappa \mathrm{B}$ to the promoter regions of inflammatory genes [11]. A range of molecular mechanisms have been investigated as possible explanations for corticosteroid insensitivity, including the overexpression of the dominant negative splice variant isoform GR $\beta$ which is associated with corticosteroid insensitivity in different cell types [41-43] and is reported to be increased in steroid resistant patients with asthma and ulcerative colitis [44-47]. Studies in COPD patients have focused on the role of histone deacetylases which are recruited by ligand activated GR to reverse the unwinding of chromatin that occurs during inflammatory gene transcription; the activity of histone deacetylases has been reported to be reduced in COPD patients, leading to decreased corticosteroid activity [23]. It has been reported that $\mathrm{GR} \alpha$ and $\beta$ expression is reduced in the peripheral lungs of COPD patients compared to controls [48]. However, we observed no difference in either GR $\alpha$ or GR $\beta$ expression by CD8 cells within lymphoid follicles in COPD compared to smoking controls. This suggests that altered GR expression level is not the mechanism responsible for the corticosteroid insensitivity observed in the current study. We did not have access to sufficient samples from nonsmoking controls for this analysis, as the majority of lung cancer patients are current or ex-smokers. Corticosteroid insensitivity is probably both a cell type and disease specific phenomenon, and further studies should address the mechanisms responsible for the corticosteroid resistance in COPD airway lymphocytes observed in the current study.

\section{Conclusions}

In conclusion, we have shown that $\mathrm{T}$ lymphocytes from the airways COPD patients display corticosteroid insensitivity. The mechanisms responsible for our findings require further study. Airway lymphocytes may play a key role in the corticosteroid insensitivity observed in COPD patients.

\section{Abbreviations}

AP-1: Activator protein 1; ATF: Activating transcription factor; BAL:

Bronchoalveolar lavage; COPD: Chronic Obstructive Pulmonary Disease; DAPI: 4,6-diamidino-2-phenylindole; FCS: Fetal calf serum; FEV 1 : Forced expired

volume in 1 second; FVC: Forced vital capacity; GR: Glucocorticoid receptor;

HNS: Healthy non smoker; IFN: Interferon; IL: Interleukin; NFAT: Nuclear factor of activated T-cells; NF-kB; Nuclear factor kappa-light-chain-enhancer of activated B cells; PHA: Phytohaemagglutinin; PMA: Phorbol myristate acetate; S: Smokers.

\section{Author details}

${ }^{1}$ University of Manchester, Manchester Academic Health Science Centre, NIHR Translational Research Facility, University Hospital of South Manchester Foundation Trust, Southmoor Road, Manchester, UK M23 9LT. ${ }^{2}$ School of Medicine, University of Manchester, Oxford Road, Manchester, UK M13 9PT. ${ }^{3}$ Centre for Parasitology and Disease, School of Environment and Life Sciences, University of Salford, Salford, UK M5 4WT. 


\section{Authors' contributions}

MK: carried out main body of lab work, data analysis and manuscript composition. LS: carried out main body of lab work and manuscript composition. PC: involved in subject recruitment, research bronchscopies, contribution to lab work and data analysis. SG: subject recruitment, research bronchsocopies and data analysis. JP: carried out the immunofluoresence work and contributed to the manuscript. DR: involved in study design, data analysis and manuscript composition, DS: involved in study design, data analysis and senior contribution to manuscript composition.

\section{Competing interests}

Manminder Kaur, Lucy Smyth, Paul Cadden, Seamus Grundy and Jonathan Plumb, have no competing interest to declare. Dave Singh and David Ray are supported by research grants as outlined in their personal declarations.

Received: 21 February 2011 Accepted: 14 March 2012

Published: 14 March 2012

\section{References}

1. Hogg JC, Chu F, Utokaparch S, Woods R, Elliott WM, Buzatu L, Cherniack RM, Rogers RM, Sciurba FC, Coxson HO, Pare PD: The nature of small-airway obstruction in COPD. N Engl J Med 2004, 24:2645-2653.

2. Agusti A, MacNee W, Donaldson K, Cosio M: Hypothesis: Does COPD have an autoimmune component? Thorax 2003, 58:832-834

3. Lee SH, Goswami S, Grudo A, Song LZ, Bandi V, Goodnight-White S, Green L, Hacken-Bitar J, Huh J, Bakeen F, Coxson HO, Cogswell S, StornessBliss C, Corry DB, Kheradmand F: Antielastin autoimmunity in tobacco smoking-induced emphysema. Nat Med 2007, 5:567-569.

4. Hodge G, Nairn J, Holmes M, Reynolds PN, Hodge S: Increased intracellular T helper 1 proinflammatory cytokine production in peripheral blood, bronchoalveolar lavage and intraepithelial T cells of COPD subjects. Clin Exp Immunol 2007, 150:22-29.

5. Majori M, Corradi M, Caminati A, Cacciani G, Bertacco S, Pesci A: Predominant TH1 cytokine pattern in peripheral blood from subjects with COPD. J Allergy Clin Immunol 1999, 103:458-462.

6. Barczyk A, Pierzchała W, Kon OM, Cosio B, Adcock IM, Barnes PJ: Cytokine production by bronchoalveolar lavage $\mathrm{T}$ lymphocytes in chronic obstructive pulmonary disease. J Allergy Clin Immunol 2006, 117:1484-1492.

7. Barceló B, Pons J, Fuster A, Sauleda J, Noguera A, Ferrer JM, Agusti AG: Intracellular cytokine profile of T lymphocytes in patients with chronic obstructive pulmonary disease. Clin Exp Immunol 2006, 145:474-479.

8. Di Stefano A, Caramori G, Capelli A, Gnemmi I, Ricciardolo FL, Oates T, Donner CF, Chung KF, Barnes PJ, Adcock IM: STAT4 activation in smokers and patients with chronic obstructive pulmonary disease. Eur Respir J 2004, 24:78-855

9. Van der Strate B, Postma D, Brandsma C, Melget B, Luinge M, Geerlings M, Hylkema $M$, van der Berg A, Timmens W, Kerstjens H: Cigarette smoke induced emphysema: a role for the B cell? Am J Respir Crit Care Med 2006, 173:751-758.

10. Lambers C, Hacker S, Posch M, Hoetzenecker K, Pollreisz A, Lichtenauer M, Klepetko W, Ankersmit H: T cell senescence and contraction of T cell repertoire diversity in patients with chronic obstructive pulmonary disease. Clin Exp Immunol 2009, 155:466-475.

11. Leung DY, Bloom JW: Update on glucocorticoid action and resistance. J Allergy Clin Immunol 2003, 111:3-22.

12. Loppow D, Schleiss MB, Kanniess F, Taube C, Jorres RA, Magnussen H: In patients with chronic bronchitis a four week trial with inhaled steroids does not attenuate airway inflammation. Respir Med 2001, 95:115-121.

13. Culpitt SV, Maziak W, Loukidis S, Nightingale JA, Matthews JL, Barnes PJ: Effect of high dose inhaled steroid on cells, cytokines and proteases in induced sputum in Chronic Obstructive Pulmonary Disease. Am J Respir Crit Care Med 1999, 160:1635-1639.

14. Soriano JB, Sin DD, Zhang $X$, Camp PG, Anderson JA, Anthonisen NR, Buist AS, Burge PS, Calverly OM, Connet JE, Petersson S, Postma DS, Szafranski W, Vestbo J: A pooled analysis of FEV1 decline in COPD patients randomized to inhaled corticosteroids or placebo. Chest 2007, 131:682-689.

15. Howe LJ, Stanford MR, Edelsten C, Graham EM: The efficacy of systemic corticosteroids in sight-threatening retinal vasculitis. Eye 1994, 8:443-447.
16. Corrigan CJ, Brown PH, Barnes NC, Szefler SJ, Tasi JJ, Frew AJ, Kay AB: Glucocorticoid resistance in chronic asthma: glucocorticoid pharmacokinetics, glucocorticoid receptor characteristics, and inhibition of peripheral blood T cell proliferation by glucocorticoids in vitro. Am Rev Respir 1991, 144:1016-1025.

17. Hearing SD, Norman M, Probert CS, Haslam N, Dayan CM: Predicting therapeutic outcome in severe ulcerative colitis by measuring in vitro steroid sensitivity of proliferating peripheral blood lymphocytes. Gut 1999, 45:382-388.

18. Kirkham BW, Corkill MM, Davison SC, Panayi GS: Response to glucocorticoid treatment in rheumatoid arthritis: in vitro cell mediated immune assay predicts in vivo responses. J Rheumatol 1991, 18:821-825.

19. Global initiative for chronic Obstructive Lung Disease. [http://www. goldCOPD.com]

20. Plumb J, Smyth $L$, Adams HR, Vestbo J, Bentley A, Singh SD: Increased T regulatory cells within lymphocyte follicles in moderate COPD. Eur Respir J 2009, 34:89-94.

21. Schroder K, Hertzog PJ, Ravasi T, Hume DA: Interferon-gamma: an overview of signals, mechanisms and functions. J Leukoc Biol 2004, 75:163-189.

22. Smith KA: Interleukin 2: inception, impact \& implications. Science 1988, 240:1169-1176.

23. Ito K, Ito M, Elliott WM, Cosio B, Caramori G, Kon OM, Barczyk A, Hayashi S, Adcock IM, Hogg JC, Barnes PJ: Decreased histone deacetylase activity in COPD. New Engl J Med 2005, 352:1967-1976.

24. Langhoff E, Jakobsen BK, Ryder LP, Svejgard A, Thaysen JH: Recipient lymphocyte sensitivity to methylprednisolone affects cadaver kidney graft survival. Lancet 1986, 327:1296-1297.

25. Goleva E, Kisich KO, Leung DY: A role for STAT5 in the pathogenesis of IL2-induced glucocorticoid resistance. J Immunol 2002, 169:5934-5940.

26. Kam JC, Szefler SJ, Surs W, Sher ER, Leung DY: Combination IL-2 and IL-4 reduces glucocorticoid receptor-binding affinity and $\mathrm{T}$ cell response to glucocorticoids. J Immunol 1993, 151:3460-3466.

27. Leung DY, Martin RJ, Szefler SJ, Sher ER, Ying S, Kay AB, Hamid Q: Dysregulation of interleukin 4, interleukin 5, and interferon- $\gamma$ gene expression in steroid-resistant asthma. J Exp Med 1995, 181:33-40.

28. Schoenborn JR, Wilson CB: Regulation of interferon-gamma during innate and adaptive immune responses. Adv Immunol 2007, 96:41-101.

29. Hens G, Vanaudenaerde BM, Bullens DM, Piessens M, Decramer M, Dupont $L$, Ceuppens JL, Hellings PW: Sinonasal pathology in nonallergic asthma and COPD: 'united airway disease' beyond the scope of allergy. Allergy 2008, 63:261-267.

30. Panzner P, Lafitte JJ, Tsicopoulos A, Hamid Q, Tulic MK: Marked upregulation of T lymphocytes and expression of interleukin- 9 in bronchial biopsies from patients with chronic bronchitis with obstruction. Chest 2003, 124:1909-1915.

31. Reeves EP, Williamson M, Byrne B, Bergin DA, Smith SG, Greally $P$, O'Kennedy R, O'Neill SJ, McElvaney NG: IL-8 dictates glycosaminoglycan binding and stability of IL-18 in cystic fibrosis. J Immunol 2010, 184:1642-1652.

32. Zhu X, Gadgil AS, Givelber R, George MP, Stoner MW, Sciurba FC, Duncan SR: Peripheral T cell functions correlate with the severity of chronic obstructive pulmonary disease. J Immunol 2009, 182:3270-3277.

33. Singh $M$, Lee $S H$, Porter $P$, Xu C, Ohno A, Atmar RL, Greenberg SB, Bandi $V$, Gern J, Amineva S, Aminev A, Skern T, Smithwock P, Perusich S, Barrow N, Roberts $L$, Corry DB, Kheradmand F: Human rhinovirus proteinase 2A induces TH1 and TH2 immunity in patients with chronic obstructive pulmonary disease. J Allergy Clin Immunol 2010, 125:1369-1378.

34. Makris D, Lazarou S, Alexandrakis M, Kourelis TV, Tzanakis N, Kyriakou D, Gourgoulianis Kl: Tc2 response at the onset of COPD exacerbations. Chest 2008, 134:483-488

35. Saetta M, Stefano AD, Turato G, Facchini FM, Corbino L, Mapp CE, Maestrelli P, Ciaccia A, Fabbri L: CD8 T-Lymphocytes in peripheral airways of smokers with chronic obstructive pulmonary disease. Am J Respir Cirt Care Med 1998, 157:822-826.

36. Saetta M, Baraldo S, Corbino L, Turato G, Braccioni F, Rea F, Cavallesco G, Tropeano G, Mapp CE, Maestrelli P, Ciaccia A, Fabbri LM: CD8+ve cells in the lungs of smokers with chronic obstructive pulmonary disease. Am J Respir Cirt Care Med 1999, 160:711-717.

37. Clarke D, Clifford RL, Jindarat S, Proud D, Pang I, Belvsi M, Knox AJ: TNFa and IFNY synergistically enhance transcriptional activation of CXCL10 in 
human airway smooth muscle cells via STAT-1, NF-KB, and the transcriptional coactivator CREB-binding protein. J Biol Chem 2010, 285:29101-29110.

38. Armstrong J, Sargent C, Singh D: Glucocorticoid sensitivity of lipopolysaccharide-stimulated chronic obstructive pulmonary disease alveolar macrophages. Clin Exp Immunol 2009, 158:74-83.

39. Kent LM, Fox SM, Farrow SN, Singh D: The effects of dexamethasone on cigarette smoke induced gene expression in COPD macrophages. Int Immunopharmacol 2010, 10:57-64

40. Chen H, Cowan MJ, Hasday JD, Vogel SN, Medvedev AE: Tobacco smoking inhibits expression of proinflammatory cytokines and activation of IL-1Rassociated kinase, p38, and NF-kappaB in alveolar macrophages stimulated with TLR2 and TLR4 agonists. J Immunol 2007, 179:6097-6106.

41. Neeck $G$, Klüter A, Dotzlaw H, Eggert M: Involvement of the Glucocorticoid Receptor in the pathogenesis of rheumatoid arthritis. Ann N Y Acad Sci 2002, 966:491-495.

42. Pujols L, Mullol J, Picado C: Alpha and beta glucocorticoid receptors: relevance in airway diseases. Curr Allergy Asthma Rep 2007, 7:93-99.

43. Pujols L, Mullol J, Torrego A, Picado C: Glucocorticoid receptors in human airways. Allergy 2004, 59:1042-1052.

44. Kraft M, Hamid Q, Chrousos GP, Martin RJ, Leung DY: Decreased steroid responsiveness at night in nocturnal asthma is the macrophage responsible? Am J Respir Crit Care Med 2001, 163:1219-1225.

45. Adcock IM, Lane SJ, Brown CR, Lee TH, Barnes PJ: Abnormal glucocorticoid receptor-activator protein 1 interaction in steroid-resistant asthma. J Exp Med 1995, 182:1951-1958.

46. Sousa AR, Lane SJ, Cidlowski JA, Staynov DZ, Lee TH: Glucocorticoid resistance in asthma is associated with elevated in vivo expression of the glucocorticoid receptor $\beta$-isoform. J Allergy Clin Immunol 2000, 105:943-950

47. Honda M, Orii F, Ayabe T, Imai S, Ashida T, Obara T: Kohgoy: Expression of glucocorticoid receptor in lymphocytes of patients with glucocorticoidresistant ulcerative colitis. Gastroenterology 2000, 118:859-866.

48. Marwick JA, Gaetano C, Stevenson CS, Casolari P, Jazrawi E, Barnes PJ, Ito K, Adcock IM, Kirkham PA, Papi A: Inhibition of PI3Kd restores glucocorticoid function in smoking-induced airway inflammation in mice. Am J Respir Crit Care Med 2009, 179:542-548.

doi:10.1186/1465-9921-13-20

Cite this article as: Kaur et al: $\mathrm{T}$ lymphocyte insensitivity to corticosteroids in chronic obstructive pulmonary disease. Respiratory Research 2012 13:20.

\section{Submit your next manuscript to BioMed Central and take full advantage of:}

- Convenient online submission

- Thorough peer review

- No space constraints or color figure charges

- Immediate publication on acceptance

- Inclusion in PubMed, CAS, Scopus and Google Scholar

- Research which is freely available for redistribution

Submit your manuscript at www.biomedcentral.com/submit
Biomed Central 